\title{
MERANGSANG PERTUMBUHAN DAN PERKEMBANGAN ANAK DENGAN PEMBELAJARAN TEMATIK TERPADU
}

\author{
Ani Hidayati \\ Universitas Islam Negeri (UIN) Walisongo Semarang \\ e-mail: ani_hidayati@yahoo.com
}

\begin{abstract}
Abstrak
Pertumbuhan dan perkembangan memiliki pengertian yang sama yakni keduanya mengalami perubahan, tetapi secara khusus istilah pertumbuhan berbeda dengan perkembangan. Pertumbuhan (growth) adalah perubahan-penubahan biologis, anatomis dan fisiologis manusia, sedangkan perkembangan(development)adalah perubahan-perubahan psikis dan motorik manusia. Pembelajaran tematik terpadu merupakan pembelajaran yang mengintegrasikan beberapa materi pembelajaran yang dipadukan dalam satu tema dimana tema tersebut sebagai wadah yang mengandung konsep sehingga pembelajaran tersebut menjadi bersifat holistik, bermakna, dan otentik. Pembelajaran tematik terpadu berfungsi untuk memberikan kemudahan bagi peserta didik dalam memahami dan mendalami konsep materi yang tergabung dalam tema serta dapat menambah semangat belajar, karena materi yang dipelajari merupakan materi yang nyata (kontekstual) dan bermakna bagi anak. Pada anak usia sekolah perkembangannya berada pada tahap operasi konkret, mulai menunjukkan perilaku yang mulai memandang dunia secara objektif, reflektif dan memandang unsur-unsur secara serentak, mulai berpikir secara operasionaluntuk mengklasifikasikan benda-benda, membentuk dan mempergunakan keterhubungan aturan-aturan, prinsip ilmiah sederhana, dan mempergunakan hubungan sebab akibat. Oleh karena itu pembelajaran yang tepat adalah dengan mengaitkan konsep materi dalam satu kesatuan yang berpusat pada tema. Kegiatan pembelajaran akan bermakna jika dilakukan dalam lingkungan yang nyaman, memberikan rasa aman, bersifat kontekstual, anak mengalami langsung sesuatu yang dipelajarinya, hal ini akan diperoleh melalui pembelajaran tematik terpadu.Pembelajaran ini relevan dengan tingkat perkembangan anak sehingga dapat merangsang pertumbuhan dan perkembangan anak.
\end{abstract}

Kata Kunci: pembelajaran tematik; pertumbuhan; perkembangan 


\section{A. Pendahuluan}

Dalam kehidupan anak terdapat dua proses yang berlangsung secara kontinu, yaitu pertumbuhan dan perkembangan. Pada umumnya penggunaan istilah "pertumbuhan" dan "perkembangan" secara bergantian. Kedua proses ini berlansung secara interdependensiartinya saling bergantung satu sama lain. Kedua proses ini tidak bisa dipisahkan dalam bentuk-bentuk yang berdiri sendiri-sendiri, akan tetapi dapat dibedakan untuk lebih memperjelas penggunaannya. Dalam hal ini kedua proses tersebut memiliki tahapan-tahapan diantaranya tahap secara moral dan spiritual. Pertumbuhan dan perkembangan peserta didik dilihat dari tahapan tersebut dapat lebih mudah menguraikannya dalam bentuk struktur yang jelas baik dari segi teori sampai kaitannya dengan pengaruh yang ditimbulkan.

Secara umum istilah pertumbuhan (growth)dan perkembangan (development) memiliki pengertian yang sama yakni keduanya mengalami perubahan. Tetapi secara khusus yakni sesuai dengan kaidah keilmuan dalam psikologi, istilah pertumbuhan berbeda dengan perkembangan. Istilah pertumbuhan mengacu pada perubahan yang bersifat kuantitas, sedangkan perkembangan lebih mengarah kepada kualitas. Artinya konsep pertumbuhan lebih mengarah ke fisik yang bersifat pasti seperti dari kecil menjadi besar, dari pendek atau rendah menjadi tinggi dan lain-lain.

Pekembangan dapat diartikan sebagai akibat dari perubahan kematangan dan kesiapan fisik yang memiliki potensi untuk melakukan suatu aktivitas, sehingga individu telah mempunyai suatu pengalaman. Dengan pengalaman ini, ia akan dapat melakukan suatu aktivitas yang sama dalam waktu mendatang. Tolok ukur untuk melihat adanya perkembangan seseorang individu ialah pada aspek kemampuan yang dimiliki sesuai dengan tahap perkembangannya.Cara dengan membandingkan keadaan satu fase dengan fase berikutnya. Apabila terjadi perbedaan dari fase sesudahnya lebih baik dari fase sebelumnya, maka individu telah mengalami fase perkembangan.

Pada usiaanak seluruh aspek perkembangan mengalami pertumbuhan dan perkembangan yang sangat luar biasa. Pada umumnya mereka masih melihat segala sesuatu sebagai satu keutuhan (berpikir holistik) dan memahami hubungan antara konsep secara sederhana. Proses pembelajaran masih bergantung kepada objek-objek yang konkret dan pengalaman yang dialami secara langsung. 
Secara sederhana, istilah pembelajaran (instruction) bermakna sebagai upaya untuk membelajarkan seseorang atau kelompok orang melalui berbagai upaya dan berbagai strategi, metode, serta pendekatan ke arah pencapaian tujuan yang telah direncanakan. ${ }^{1}$ Sedangkan Pembelajaran tematik tepadu merupakan pembelajaran yang mengintegrasikan beberapa materi pembelajaran yang dipadukan dalam satu tema dimana tema tersebut sebagai wadah yang mengandung konsep sehingga pembelajaran tersebut menjadi bersifat holistik, bermakna, dan otentik.

Melalui pembelajaran tematik ini anak akan terpacu kreativitasnya karena dalam pembelajaran ini anak diberikan wadah dalam mengeksplorasi pengetahuan yang telah dimilikinya, sehingga anak akan mampu mengembangkan potensi yang dimiliki. Kemudian pembelajarannya juga tidak akan membosankan, karena pembelajaran bersifat aktual sesuai dengan lingkungan kesehariannya.

Dengan menerapkan pembelajaran tematik terpadu maka anak diharapkan dapat belajar secara menyenangkan lebih bermakna dan bersifat alamiah karena setiap tahapan dalam proses pembelajaran diperhatikan sehingga dengan pembelajaran tematik terpadu ini dapat merangsang pertumbuhan dan perkembangan anak.

\section{B. Pertumbuhan dan Perkembangan Anak}

Pertumbuhan (growth) merupakan peningkatan jumlah dan besar sel diseluruh bagian tubuh. Pertumbuhan adalah perubahan secara fisiologis sebagai hasil dari proses pematangan fungsi-fungsi fisik yang berlangsung secara normal pada anak yang sehat pada waktu yang normal. Pertumbuhan dapat juga diartikan sebagai proses transmisi dari konstitusi fisik (keadaan tubuh atau keadaan jasmaniah) yang herediter dalam bentuk proses aktif secara berkesinambungan. Sedangkan perkembangan (development), adalah perubahan secara berangsur-angsur dan bertambah sempurnanya fungsi alat tubuh, meningkat dan meluasnya kapasitas seseorang melalui pertumbuhan, kematangan, atau kedewasaan, dan pembelajaran. Pertumbuhan dan perkembangan tingkah laku anak-anak tidak sederhana saja, tetapi mempunyai seluk beluk sangat komplek dan waktu berlangsung-

${ }^{1}$ Abdul Majid, Starategi Pembelajaran, (Bandung: Remaja Rosdakarya, 2013), h. 4. 
nya panjang yaitu dari embrio sampai dewasa maka perlu pembagian waktu tahap-tahap perkembangannya, perlu periodisasi perkembangan anak. ${ }^{2}$

Secara umum istilah pertumbuhan dan perkembangan memiliki pengertian yang sama yakni keduanya mengalami perubahan, tetapi secara khusus istilah pertumbuhan berbeda dengan perkembangan. Istilah pertumbuhan mengacu pada perubahan yang bersifat kuantitas, sedangkan perkembangan lebih mengarah kepada kualitas.Konsep pertumbuhan lebih mengarah ke fisik yang bersifat pasti seperti dari kecil menjadi besar, dari pendek atau rendah menjadi tinggi dan lain-lain. Sifat dari pertumbuhan tidak dapat kembali ke bentuk semula, contohnya dari pendek menjadi tinggi tetapi tidak mungkin dari tinggi menjadi pendek lagi. Selain itu yang terpenting dari pertumbuhan adalah terjadinya proses pematangan fisik yang ditandai dengan makin kompleksnya sistem jaringan otot, sistem saraf maupun fungsi organ tubuh, kematangan tersebut menyebabkan organ fisik merasa siap untuk dapat melakukan tugas-tugas dan aktivitas sesuai dengan tahap perkembangan individu. Di saat inilah anak mulai mampu berkembang dan melakukan aktivitas untuk mengembangkan seluruh potensi kognitif, dan afeksi dengan baik.

Perkembangan dapat diartikan sebagai akibat dari perubahan kematangan dan kesiapan fisik yang memiliki potensi untuk melakukan suatu aktivitas, sehingga individu telah mempunyai suatu pengalaman. Dengan pengalaman ini, ia akan dapat melakukan suatu aktivitas yang sama dalam waktu mendatang. Tolok ukur untuk melihat adanya perkembangan seseorang individu ialah pada aspek kemampuan yang dimiliki sesuai dengan tahap perkembangannya.Dengan membandingkan keadaan satu fase dengan fase berikutnya maka apabila terjadi peningkatan pada fase sesudahnya dari pada fase sebelumnya, maka individu telah mengalami fase perkembangan.

Pertumbuhan merupakan perubahan-perubahan biologis, anatomis dan fisiologis manusia, misalnya perubahan dari bentuk tubuh bayi menjadi kanak-kanak, dari kanak-kanak berubah menjadi remaja, remaja menjadi orang dewasa. Sedangkan perkembangan merupakan perubahan-perubahan psikis dan motoriknya, misalnya belajar berjalan, belajar berbahasa, bermain, berpikir konkret, berpikir abstrak, dan sebagainya. ${ }^{3}$

${ }^{2}$ Ki Fudyartanta, Psikologi Perkembangan, (Yogyakarta: Pustaka Pelajar, 2012), h. 81.

3Ibid., h. 266. 
Setiap individu yang normal akan mengalami pertumbuhan dan perkembangan. Hal ini dimulai sejak masih dalam kandungan hingga kelahiran menjadi bayi, kemudian tumbuh berkembang menjadi anak-anak, remaja, dewasa hingga ia mati. Para ahli psikologi perkembangan membagi tahapan periodisasi perkembangan sebagai berikut:

\section{Masa Pra-Natal}

Masa pra-natal dimulai ketika pertemuan antara spermatozoon dengan sel telur yang kemudian berubah menjadi calon manusia. Proses tersebut berlangsung kurang lebih 9 bulan 10 hari atau 42-43 minggu. Para ahli menyebutnya sebagai masa perubahan evolisi janin dalam kandungan. Kondisi janin dalam kandungan sangat rentan terhadap pengaruh lingkungan hidupnya, yakni seberapa jauh ibunya memiliki taraf kesehatan, kebiasaan dan perilaku yang baik atau tidak. Kondisi fisik dan psikologi yang baik akan membuat individu tumbuh berkembang sebagai orang yang sehat. Cerdas dan kompeten. Sebaliknya jika kondisi yang tidak menguntungkan (suami istri penuh konflik, ibu dalam keadaan sakit, memiliki kebiasaan merokok atau narkoba) maka bayi yang dilahirkan memiliki resiko gangguan fisik, gangguan mental atau gangguan perilaku.

\section{Masa Bayi dan Anak Tiga Tahun Pertama}

Kohnstam menyebutkan masa ini dengan periode vital yang artinya penting. Jadi, masa bayi dianggap sebagai masa perkembangan yang sangat penting, karena anak mengalami perubahan yang sangat pesat dalam perkembangan jasmani dan rohaninya. ${ }^{4}$ Setelah dalam kandungan selama kurang lebih 9 bulan 10 hari bayi siap untuk dilahirkan ke dunia. Setelah dilahirkan seorang bayi segera menangis sebagai tanda berfungsinya perasaan dan panca indra dalam menghadapi penyesuaian diri dengan lingkungan hidupnya yang baru. Kalau sebelumnya ia hidup di dalam kandungan dengan nyaman dan tenang, ketika lahir ia harus beradaptasi. Perasaan kaget dan terkejut (shock) yang dirasakan pertama kali ditandai dengan menangis.Kemudian seorang bayi mengalami pertumbuhan dan berkembangan selama masa pengasuhan, pemeliharaan dan bimbingan dari orangtuanya. Si anak akan belajar untuk mengembangkan keterampilan

${ }^{4}$ Zulkifli L, Psikologi Perkembangan, (Bandung: Remaja Rosda Karya, 2009), h. 2. 
motorik, dengan merangkak, berdiri, berjalan, melompat dan berlari. Kegiatan yang cukup menyenangkan bagi anak ialah masa bermain-main. Dengan bermain anak dapat mengembangkan keterampilan motorik, kecerdasan, inisiatif, imajinasi, kreativitas, bakat, kemampuan sosialisasi. Bermain adalah sarana proses pembelajaran diri yang diperoleh melalui interaksi dengan lingkung fisik maupun lingkungan sosial disekitarnya. Selain itu, ciri yang lebih spesifik pada masa anak dibawah tiga tahun adalah kelekatan emosi dengan orangtua, takut berpisah dengan orang tua, biasanya suka membuat cerita yang tidak masuk akal, dan egosentris. ${ }^{5}$

\section{Masa Anak-anak Awal (Early Childhood)}

Secara kronologi usia periode ini dialami oleh anak yang berada pada usia 4-5 tahun.Walaupun anak pada masa ini masih terikat dan memfokuskan diri pada orangtua atau keluarga, namun pada masa anak ini, ditandai dengan kemandirian, kemampuan kontrol fisik (self control) dan hasrat untuk memperluas pergaulan dengan anak-anak yang sebaya. Pergaulan yang makin luas ini akan mengurangi sifat egosentrisme, mengurangi sifat yang tidak mungkin, kelekatan dengan orang tua berkurang, karena dalam masa pergaulan itu masing-masing anak saling mengkritik, mencela, mengejek, mungkin terjadi konflik, pertengkaran yang kemudian diikuti dengan proses pembuatan kompromi, adaptasi normanorma yang berlaku. Proses ini ditandai dengan kegiatan bermain baik sendiri maupun dengan kelompok teman sebaya.

\section{Masa Anak Tengah (Middle Childhood)}

Masa ini dialami oleh anak yang berumur kira-kira 7-9 tahun.Pada masa ini kehidupan anak-anak tengah diwarnai dengan kekompakan kelompok teman sebaya yang berkelamin sejenis. Masa ini menurut pandangan Erik erikson menyebutkan masa anak-anak tengah sebagai masa industri. Anak-anak mulai mengembangkan kepribadian seperti pembentukan konsep diri fisik, sosial dan akademis. Masa ini dapat dikatakan juga sebagai masa pengembangan potensi intelektual maupun sosialisasi.

${ }^{5}$ Dariyo, Ahmad, Psikologi Perkembangan Anak Usia Tiga Tahun Pertama, (Bandung: PT Refika aditama, 2007), h. 38. 
Karakteristik yang dimiliki anak pada usia ini antara lain: matang untuk memulai menulis, membaca, dan berhitung. ${ }^{6}$

\section{Masa Anak Akhir (Late Childhood)}

Para ahli menyebutnya sebagai masa anak-anak yaitu pada usia 1012tahun.Pada masa ini anak sudah memiliki rasa ketertarikan terhadap lawan jenis. Menurut Piaget, anak-anak terus mengembangkan kapasitas intelektual di bangku pendidikan formal yakni sekolah dasar. Tak kalah pentingnya ialah meningkatnya aktivitas yang banyak menyita energi fisik, akibat pertumbuhannya yang mendekati masa proses kematangan yakni masa remaja. Karakteristik anak pada usia ini antara lain: (1) Perkembangan perasaan intelek, contoh: menyelesaikan soal-soal matematika, (2) Perasaan seksual, contoh: mulai tertarik pada lawan jenis, (3) Perasaan keagamaan, contoh: melakukan perbuatan baik, (3) Rasa sosial, contoh: solidaritas dengan teman sebaya, (4) Perkembangan kemauan, contoh: melakukan kritik sederhana. ${ }^{7}$

\section{Masa Remaja (Adolescence)}

Masa remaja merupakan kelanjutan dari masa anak-anak akhir. Masa remaja merupakan masa transisi (peralihan) untuk menuju masa dewasa yanng pada usia anak 13-21 tahun. Masa remaja memiliki ciri pertumbuhan fisik yang relatif cepat.Organ-organ fisik mencapai taraf kematangan yang memungkinkan berfungsinya sistem reproduksi dengan sempurna. Konsekuansinya apabila mereka melakukan hubungan seksual maka akan dapat mengakibatkan kehamilan. Oleh karena itulah orang tua mulai mencemaskan keberadaan anak-anaknya yang telah menginjak masa remaja. Sementara itu remaja mulai tak mau dikekang atau dibatasi oleh aturan. Mereka ingin memperoleh kesempatan untuk mengembangkan diri guna mewujudkan jati diri. Hanya saja cara berfikir mereka cenderung egosentris dan sulit untuk memahami pola pikir orang lain. Itulah sebabnya, biasanya antara remaja dan orangtua sering mengalami konflik.Bila tak terselesaikan dengan baik, maka hal ini cenderung menyebabkan masalah keluarga. ${ }^{8}$

${ }^{6}$ Zulkifli L, Psikologi Perkembangan, h. 53.

${ }^{7}$ Ibid., h. 59.

${ }^{8}$ Dariyo, Ahmad, Psikologi Perkembangan Anak Tiga Tahun Pertama, h. 40. 
Sedangkan menurut pendapatAristoteles, menyebutkan periodisasi ada tiga, sebagai berikut: a) Periode I: dari usia anak 0,0-7,0 tahun (periode anak kecil), b) Periode II: dari usia anak 7,0-14,0 tahun (periode sekolah), c) Periode III: dari usia anak 14,0-21,0 tahun (periode pubertas, masa peralihan dari usia anak menjadi dewasa). ${ }^{9}$

Dengan demikian periodisasi perkembangan pada manusia adalah tahap-tahap perubahan yang terjadi pada manusia, tahap-tahap perubahan tersebut berupa akal pikiran, perilaku dan lain-lain. Pertumbuhan berpengaruh pada perkembangan anak, maksudnya bahwa cara berpikir anak akan sesuai dengan tingkatan usianya seperti cara berfikir dan berperilaku anak usia balita akan berbeda dengan anak usia remaja.

\section{Pembelajaran Tematik Terpadu}

Secara sederhana, istilah pembelajaran (instruction) bermakna sebagai upaya untuk membelajarkan seseorang atau kelompok orang melalui berbagai upaya (effort) dan berbagai strategi, metode, dan pendekatan ke arah pencapaian tujuan yang telah direncanakan. ${ }^{10}$ Pembelajaran tematik merupakan pembelajaran yang mengintegrasikan beberapa materi pembelajaran yang dipadukan dalam satu tema dimana tema tersebut sebagai wadah yang mengandung konsep sehingga pembelajaran tersebut menjadi bersifat holistik, bermaknadan otentik.

Pembelajaran tematik terpadu dilaksanakan dengan menggunakan prinsip pembelajaran terpadu. Pembelajaran terpadu menggunakan tema sebagai pemersatu kegiatan pembelajaran yang memadukan beberapa mata pelajaran sekaligus dalam satu kali tatap muka, untuk memberikan pengalaman yang bermakna bagi peserta didik. Peserta didik dalam memahami berbagai konsep yang mereka pelajari selalu melalui pengalaman langsung dan menghubungkannya dengan konsep lain yang telah dikuasainya. ${ }^{11} \mathrm{Pe}-$ laksanaan pembelajaran tematik terpadu berawal dari tema yang telah dipilih/dikembangkan oleh guru yang sesuai dengan kebutuhan peserta didik. Jika dibandingkan dengan pembelajaran konvensional pembelajaran

\footnotetext{
9Susanto, Ahmad, Perkembangan Anak Usia Dini Pengantar dalam Berbagai Aspeknya, (Jakarta: Kencana Prenada Media Group, 2012), h. 26.

${ }^{10}$ Abdul Majid, Starategi Pembelajaran, h. 4.

${ }^{11}$ Sofiyanti, Ai. "Pembelajaran Tematik dalam Implementasi Kurikulum 2013", Makalah TOT Pembelajaran Tematik pada Program DMS, Jakarta, 2013, h. 7.
} 
tematik ini tampak lebih menekankan pada tema sebagai pemersatu berbagai mata pelajaran yang lebih diutamakan pada makna belajar, dan keterkaitan berbagai konsep mata pelajaran. Keterlibatan peserta didik dalam belajar lebih diprioritaskan dan pembelajarannya bertujuan mengaktifkan peserta didik, memberikan pengalaman langsung serta tidak tampak adanya pemisahan antar mata pelajaran satu dengan lainnya.

Pembelajaran tematik terpadu berfungsi untuk memberikan kemudahan bagi peserta didik dalam memahami dan mendalami konsep materi yang tergabung dalam tema serta dapat menambah semangat belajar, karena materi yang dipelajari merupakan materi yang nyata (kontekstual) dan bermakna bagi peserta didik. ${ }^{12}$ Adapun tujuan pembelajaran tematik terpadu adalah:

1. Mudah memusatkan perhatian pada satu tema atau topik tertentu.

2. Mempelajari pengetahuan dan mengembangkan berbagai kompetensi mata pelajaran dalam tema yang sama.

3. Memiliki pemahaman terhadap materi pelajaran lebih mendalam dan berkesan.

4. Mengembangkan kompetensi berbahasa lebih baik dengan mengkaitkan berbagai mata pelajaran lain dengan pengalaman pribadi peserta didik.

5. Lebih bergairah belajar karena mereka dapat berkomunikasi dalam situasi nyata, seperti: bercerita, bertanya, menulis sekaligus mempelajari pelajaran yang lain.

6. Lebih merasakan manfaat dan makna belajar karena materi yang disajikan dalam konteks tema yang jelas

7. Guru dapat menghemat waktu, karena mata pelajaran yang disajikan secara terpadu dapat dipersiapkan sekaligus dan diberikan dalam 2 atau 3 pertemuan

8. Akhlak dan moral peserta didik dapat ditumbuhkembangkan dengan mengangkat sejumlah nilai-nilai yang sesuai dengan situasi dan kondisi.

Dalam pelaksanaannya pembelajaran tematik terpadu memiliki ciri-ciri sebagai berikut: a) Berpusat pada anak, b) Memberikan pengalaman lang-

${ }^{12}$ Ibid., h. 8. 
sung pada anak, c) Pemisahan antara mata pelajaran tidak begitu jelas (menyatu dalam satu pemahaman dalam kegiatan), d) Menyajikan konsep dari berbagai mata pelajaran dalam satu proses pembelajaran (saling terkait antara mata pelajaran yang satu dengan lainnya), e) Bersifat luwes (keterpaduan berbagai mata pelajaran), f) Hasil pembelajaran dapat berkembang sesuai dengan minat dan kebutuhan anak (melalui penilaian proses dan hasil belajarnya). ${ }^{13}$

\section{Pembelajaran Tematik Terpadu Relevan dengan Tingkat Perkembangan Anak}

Perkembangan anak pada usia sekolah berada pada tahapan operasi konkret yangmulai menunjukkan perilakuuntuk memandang dunia secara objektif, bergeser dari satu aspek situasi ke aspek lain secara reflektif dan memandang unsur-unsur secara serentak, mulai berpikir secara operasional, mempergunakan cara berpikir operasional untuk mengklasifikasikan bendabenda, membentuk dan mempergunakan keterhubungan aturan-aturan, prinsip ilmiah sederhana, dan mempergunakan hubungan sebab akibat. Oleh karena itu pembelajaran yang tepat adalah dengan mengaitkan konsep materi pelajaran dalam satu kesatuan yang berpusat pada tema yang biasa dsebut pembelajaran tematik terpadu.

Pembelajaran tematik ini dikembangkan menurut paham konstruktivisme yang menyatakan bahwa pengetahuan dibentuk sendiri oleh individu dan pengalaman merupakan kunci utama dari belajar bermakna. Belajar bermakna tidak akan terwujud hanya dengan mendengarkan ceramah atau membaca buku tentang pengalaman orang lain. Pengalaman secara individual merupakan kunci kebermaknaan.

Teori konstruktivisme menyatakan bahwa siswa harus menemukan sendiri dan mentransformasikan informasi kompleks, siswa benar-benar memahami dan dapat menerapkan pengetahuan, mereka harus bekerja memecahkan masalah, menemukan segala sesuatu untuk dirinya, berusaha dengan susah payah dengan ide-ide. ${ }^{14}$

Prinsip-prinsip konstruktivisme yang dikembangkan pada pembelajaran terpadu yaitu: 1) Pengetahuan dibangun oleh siswa sendiri, 2) Pengetahuan

\footnotetext{
${ }^{13} \mathrm{Ibid} .$, h. 9.

${ }^{14}$ Trianto, Mendesain Model Pembelajaran Inovatif-Progresif, (Jakarta: Kencana, 2010), h. 28.
} 
tidak dapat dipindahkan dari guru ke murid, kecuali hanya dengan keakifan murid sendiri untuk menalar, 3) Murid aktif mengonstruksi terus menerus, sehingga selalu terjadi perubahan konsep menuju ke konsep yang lebih rinci, lengkap dan sesuai dengan konsep ilmiah, 4) Guru sekadar membantu menyediakan sarana dan situasi agar proses konstruksi siswa berjalan mulus.

Atas dasar ini siswa akan memiliki pemahaman yang berbeda berdasarkan pengetahuan yang telah dikonstruksi dari pengalaman yang dialaminya sendiri. Melalui pembelajaran tematik ini siswa akan terpacu kreativitasnya karena dalam pembelajaran ini siswa diberikan wadah dalam mengeksplorasi pengetahuan yang telah dimilikinya. Kemudian pembelajaran juga tidak akan membosankan, karena pembelajaran bersifat aktual sesuai dengan lingkungan kesehariannya.

Sebagai suatu model pembelajaran di sekolah/madrasah, pembelajaran tematik memiliki karakteristik-karakteristik sebagai berikut: 1) Berpusat pada siswa (Student Centered), 2) Memberikan pengalaman langsung, 3) Pemisahan mata pelajaran tidak begitu jelas, 4) Menyajikan konsep dari berbagai mata pelajaran, 5) Bersifat fleksibel, 6) Menggunakan prinsip belajar sambil bermain dan menyenangkan, 7) Holistik atau utuh, 8) Bermakna, 9) Autentik, 10) Aktif.

Dari karakteristik pembelajaran tematik yang sudah diuraikan di atas, dapat dikatakan bahwa pembelajaran tematik itu relevan dengan tingkat perkembangan anak karena dalam pelaksanaannya dapat: 1) Memberikan pengalaman dan kegiatan belajar mengajar yang relevan dengan tingkat perkembangan dan kebutuhan anak. 2) Menyenangkan karena bertolak dari minat dan kebutuhan. 3) Hasil belajar dapat bertahan lama karena lebih berkesan dan bermakna. 4) Mengembangkan keterampilan berpikir anak sesuai dengan permasalahan yang dihadapi. 5) Menumbuhkan keterampilan sosial dalam bekerja sama. 6) Memiliki sikap toleransi, komunikasi dan tanggap terhadap gagasan orang lain, dalam arti respek terhadap gagasan orang lain. 7) Menyajikan kegiatan yang bersifat pragmatis sesuai dengan permasalahan yang sering ditemui dalam lingkungan anak.

Kegiatan pembelajaran tematik ini akan memberikan pengalaman yang bermakna jika dilakukan dalam lingkungan yang nyaman, memberikan rasa aman, bersifat kontekstual, serta menyenangkan sehingga anak dapat belajar denganmengalami langsung tentang sesuatu yang dipelajari- 
nya tanpa terpaksa, sehingga pembelajaran ini dapat merangsang pertumbuhan dan perkembangan anak.[]

\section{Daftar Pustaka}

Dariyo, Ahmad, Psikologi Perkembangan Anak Tiga Tahun Pertama, Bandung: Refika Aditama, 2007.

Desmita, Psikologi Perkembangan, Bandung: Rosda Karya, 2005.

Elizabeth B. Hurlock, Psikologi Perkembangan; Suatu Pendekatan Sepanjang Rentang Kehidupan, Jakarta: Elangga, 2003.

Hastuti, Psikologi Perkembangan Anak, Yogyakarta: Tugu Publisher, 2012.

Herry Hernawan, Asep dan Novi Resmini, Pembelajaran Tematik, Jakarta: Direktorat Jenderal Pendidikan Islam Kementerian Agama RI, 2009.

Kadir, Abdul dan Hanun Asrohah, Pembelajaran Tematik, Jakarta: Rajawali Perss, 2014.

Kemdikbud, Implementasi Pembelajaran Tematik Terpadu dengan Pendekatan Scientifik, Jakarta: Kemdikbud, 2013.

Ki Fudyartanta, Psikologi Perkembangan. Yogyakarta: Pustaka Pelajar, 2012.

Majid, Abdul, Pembelajaran Tematik Terpadu, Bandung: Remaja Rosdakarya, 2014.

, Starategi Pembelajaran. Bandung: Remaja Rosdakarya, 2013.

Yamin, Martinis, Paradigma Pendidikan Konstruktivistik, Jakarta: Gaung Pesada Press, 2008.

Rusman, Model-model Pembelajaran: Mengembangkan Profesionalisme Guru, Jakarta: Rajawali Perss, 2011.

Slavin, Robert E., Psikologi Pendidikan: Teori dan Praktik, Jakarta: Indeks, 2011.

Sofiyanti, Ai, "Pembelajaran Tematik dalam Implementasi Kurikulum 2013", Makalah TOT Pembelajaran Tematik pada Program DMS, Jakarta, 2013.

Susanto, Ahmad, Perkembangan Anak Usia Dini Pengantar dalam Berbagai Aspeknya, Jakarta: Kencana Prenada Media Group, 2011.

Trianto, Desain Pengembangan Pembelajaran Tematik bagi Anak Usia Dini TK/RA dan Anak Usia Kelas Awal SD/MI, Jakarta: Kencana, 2013. 
Mendesain Model Pembelajaran Inovatif-Progresif, Jakarta: Kencana, 2010.

Zulkifli, L., Psikologi Perkembangan, Bandung: PT Remaja Rosdakarya, 2009. 
